\title{
Differential RNA editing of mitochondrial atp1 gene in Catharanthus roseus tissues
}

\author{
Huda Alhamdan 1, ${ }^{*}$, Wasimah B Alshammari 1,2, Thana Khan ${ }^{1}$, Sherif Edris ${ }^{1,3}$, Sameh E. Hassanein ${ }^{4,5}$ \\ Ahmed M Ramadan ${ }^{1,6}$ \\ ${ }^{1}$ Department of Biological Sciences, Faculty of Sciences, King Abdulaziz University, Jeddah, Saudi Arabia. \\ ${ }^{2}$ Department of biology, faculty of science, Hail University, Hail, Saudi Arabia. \\ ${ }^{3}$ Department of Genetics, Faculty of Agriculture, Ain Shams University, Cairo, Egypt. \\ ${ }^{4}$ Bioinformatics and Computer Networks Department, Agricultural Genetic Engineering Research Institute (AGERI), Agriculture Research Center (ARC), Giza, \\ Egypt. \\ ${ }^{5}$ College of Biotechnology, Misr University for Science and Technology (MUST), 6th October city, Egypt. \\ ${ }^{6}$ Agricultural Genetic Engineering Research Institute (AGERI), Agriculture Research Center (ARC), Giza, Egypt
}

Correspondence Author: Huda Alhamdan, Department of Biological Sciences, Faculty of Sciences, King Abdulaziz University, Jeddah, Saudi Arabia. Email: h.alhamdan2@gmail.com

Received date: 12 December 2019, Accepted date: 28 February 2020, Online date: 29 March 2020

Copyright: (C) 2020 Alhamdan et al., This is an open-access article distributed under the terms of the Creative Commons Attribution License, which permits unrestricted use, distribution, and reproduction in any medium, provided the original author and source are credited.

\begin{abstract}
RNA editing is a posttranscriptional modification. This modification is executed by insertion, deletion or nucleotide substitution. ATP synthase subunit1 (ATP1) gene is encoded to the alpha subunit of complex V which is indispensable for generating mitochondrial ATP. RNA editing in this gene was investigated in many plants like Arabidopsis and Gossypium hirsutum. In this study, five RNA editing sites were in ATP1 gene transcripts in different Catharanthus roseus tissues using high throughput sequencing. Editing sites (C1039, C1178, C1292, C1415, and C1490) were identified from $\mathrm{C}$ to $\mathrm{T}$ substitution in $C$. roseus tissues. Results indicate that RNA editing in $A T P 1$ varies across $C$. roseus tissues. Three edits of $A T P 1$ gene transcripts $(\mathrm{C1039}, \mathrm{C} 1292$ and $\mathrm{C1415})$ were detected in all $C$. roseus tissues. The most frequent number of edits appeared in flower and leaf $A T P 1$ tissues of $C$. roseus compared to other tissues. A C1178 edit of $A T P 1$ transcript was only observed in flower, leaf and hairy root of $C$. roseus, whereas it was absent in root, stem and seedling. Furthermore, $\mathrm{C} 1490$ site of this gene was recognized in all $C$. roseus tissues except in hairy root tissue. Differential editing of $A T P 1$ gene transcript might control the rate of ATP production.
\end{abstract}

Keywords: RNA editing, atp1 gene, Catharanthus roseus

\section{INTRODUCTION}

RNA editing is one of the posttranscriptional modifications executed by insertion, deletion, or nucleotide substitution [1]. RNA editing was found in humans, animals, fungi and plants [2, 3], and recently in prokaryotes[4]. RNA editing sites convert Cytidine to Uridine ( $\mathrm{C}$ to $\mathrm{U}$ ) [5] or Adenine to Inosine (A to I) [6] and rarely Uridine to Cytosine (U to C) [7]. These edits reprogrammed the immature mRNA, causing a new amino acid and producing a new protein. This new gene product might acquire diverse characters that could affect its function [8,9].

In the plant, RNA editing process exceeds commonly in both plastid and mitochondria [10], the Arabidopsis plastid genome has 43 editing sites [11] and mitochondrial genome has 619 editing sites [1]. The cytidine to uridine conversion is the most usual RNA editing over the particular nitrogen-containing base in the blossoming plant [12].

Various studies have illustrated that the five mitochondrial complexes (complex I, II, III, etc.) have their mitochondrial genes [13]. ATPs genes are components of the ATP synthase complex group (complex V), which have a vital role in cellular respiration metabolism, including subunit genes (ATP1, ATP2, ATP3, ATP4, etc.) [14]. ATP1, ATP6, ATP4, $A T P 9$ and $A T P 8$ were encoded from the plant mitochondrial genome $[15,16]$ Complex $\mathrm{V}$ enzyme, including ATP 
genes group, is the last step of oxidative phosphorylation and has the responsibility of generating energy to the tissue. Therefore, it could be correlated with decreasing or increasing the level of tissue growth [17].

The alpha subunit of mitochondrial ATP synthase is encoded by ATP1 [18, 19]. Many reports have investigated that RNA editing in atpl was associated with some physiological traits like cytoplasmic male sterility, fibre cell elongation, an increasing number of leaf trichomes, and root length [20, 21]. In contrast, Mutation in editing site atp1-1178 caused delays in Arabidopsis growth and development [22]. This study focusses on the tissue specificity of RNA editing of ATPI gene in C. roseus across the different plant tissues

\section{METHODOLOGY}

\subsection{DNA and RNA Sequence data}

DNA-seq of $C$. roseus (accession no. PRJNA417297) was described by [23]. RNA-seq data C. roseus was gathered and downloaded from Gene Bank at the National Center for biotechnology information advances science and health (NCBI) as following; SRR122253 stem, SRR122258 hairy root, SRR342017 leaf, SRR1271858 root, SRR1271859 flower, SRR5133636 seedling [24, 25].

\section{Sequence analysis}

The DNA raw data was consisted of about 72 million of $100 \mathrm{bp}$ paired-end reads. The parameters were optimized according to [23]. Adapter sequences were trimmed and read with low-quality bases were filtered. High-quality reads (>20) were then assembled separately to Razya stricta mitochondrial atp1 as a reference gene (NCBI accession no. KJ485850) using the CLC Genomics Workbench 3.6.5 software with parameters of length fraction $\geq 50 \%$ and identity $\geq 80 \%$. The same software was used to identify the atp1 transcript using the obtained C. roseus atpl DNA gene as a reference. The ATP1 transcripts of $C$. roseus tissues were assembled from RNA-seq data 84,355,826 paired-end reads in flower, 57,807,858 paired-end reads in the stem, 123,982,796 paired-end reads in leaf, 130,804,028 paired-end reads in the hairy root, 89,052,194 paired-end reads in root and 132,062,664 paired-end reads in the seedling. Then, the RNA editing positions, counts of total read and depth of coverage were identified. The nucleotide conversion frequency of each site was evaluated according to reads number for converting nucleotide divided by total reads [26].

\section{Multi sequence alignment}

The genomic and cDNA sequences of mitochondrial ATPI gene of $C$. roseus obtained in the present study were analyzed for RNA editing status using multi-sequence alignment and using a CLC genomic workbench 3.6.5 (http://www.clcbio.com/products/clc-genomics-workbench). Also, protein multi-sequence alignment was achieved using the same program.

\section{RNA editing sites validation and analysis using RT-qPCR}

Biological triplicate samples of each tissue were used to validate predicted editing sites from RNA-seq data. Total RNA of all samples was extracted using Qiazol (Qiagen, Cat No. 79306).

To validate RNA editing sites, each cDNA synthesis reaction was containing $1 \mu \mathrm{g}$ of total RNA, $1 \mu \mathrm{M}$ poly dT oligonucleotide (Biolegio, Nijmegen, Netherlands). The RT-PCR reaction was enforced according to [27]. PCR amplification was done using primers designed by Primer-Blast (https://www.ncbi.nlm.nih.gov/tools/primerblast/index.cgi?LINK_LOC=BlastHome). Primers were designed as two forward specific primers with different $3^{\prime}$ end (original and substitute nucleotide) and one reverse primer, for each editing site (Table 2). \%RNA editing is performed according to [27]:

$\%$ RNA editing $=2(\mathrm{Ct}$ mean of $\mathrm{T}$ variant $-\mathrm{Ct}$ mean of $\mathrm{C}$ variant $) / \quad\{2(\mathrm{Ct}$ mean of $\mathrm{T}$ variant $-\mathrm{Ct}$ mean of $\mathrm{C}$ variant $)$ $+1\} \times 100$.

\section{ATP measurement}

Biological samples were collected from stem, hairy root, flower, root and leaves of three-month-old plants, and seedling 3 weeks old plants of $C$. roseus SunStorm ${ }^{\mathrm{TM}} \mathrm{cv}$. Apricot. Plants were grown at $22^{\circ} \mathrm{C}$ in a growth chamber with 14 hours light as described [23]. ATP was extracted from leaves by a trichloroacetic acid method [28]. The level of ATP e directly measured by the ATP Bioluminescence Assay Kit CLS II (Merck, 11699695001). Standard curves of $0-40$ authentic pmol standards were freshly prepared on the day of measurement

\section{RESULTS AND DISCUSSION}

ATP is essential to promote cell growth and provide energy to face different stress. In plants, mitochondria and chloroplasts coordinate activity to produce enough ATP to meet the energy requirements of anabolic processes [29]. 
ATP1 is a subunit of complex $\mathrm{V}$ of the electron transport chain in mitochondria, and it belongs to mitochondria genes. ATP1 gene is encoded to alpha-beta of F1 subunit. This subunit is an essential subunit of ATP synthase that has a liability of supplying energy for the cells[18]. Recently, RNA editing in ATP synthase has been found to play an essential role in energy production, in other means, efficiency in ATP production associated with increasing in RNA editing sites [20]. In some plants, the absence of RNA editing in ATP subunit 1 caused CMS [30]. The benefit of edits occurrence might be necessary to produce vigour crop with adaptive properties to the environment [20]. In this study, we focused on RNA editing of the mitochondrial ATPl gene.

\section{Characterization of $C$. roseus ATP1gene:}

First mitochondrial C. roseus Atpl was characterized (accession no. MK424833). The obtained ATP1 sequence was aligned using BLAST search hits. Nine species were closely related to ATPl gene of $C$. roseus with the 0.0 e- value and 99 percentage of identity. Ninety-eight percentages of similarity level appeared between ATP1 gene of C. roseus and Sipanea sp. NW-2017 with 0.0 e-value (Table1).

\section{Conserved domain analysis}

Many investigators used Conserved domain analysis to identify protein function [31-33]. Domain analysis specified the appearances of ATP synthase F1 subunit 1 (atp1). Conserved domain database accession number cl35802, and pfam accession number pf 00006 (Fig.1). Although this analysis is used to classify protein into families and identify functional locales, different activities among editing gene transcripts and their actual sequences which are based on peptide grouping cannot appear in the domain database strategy.

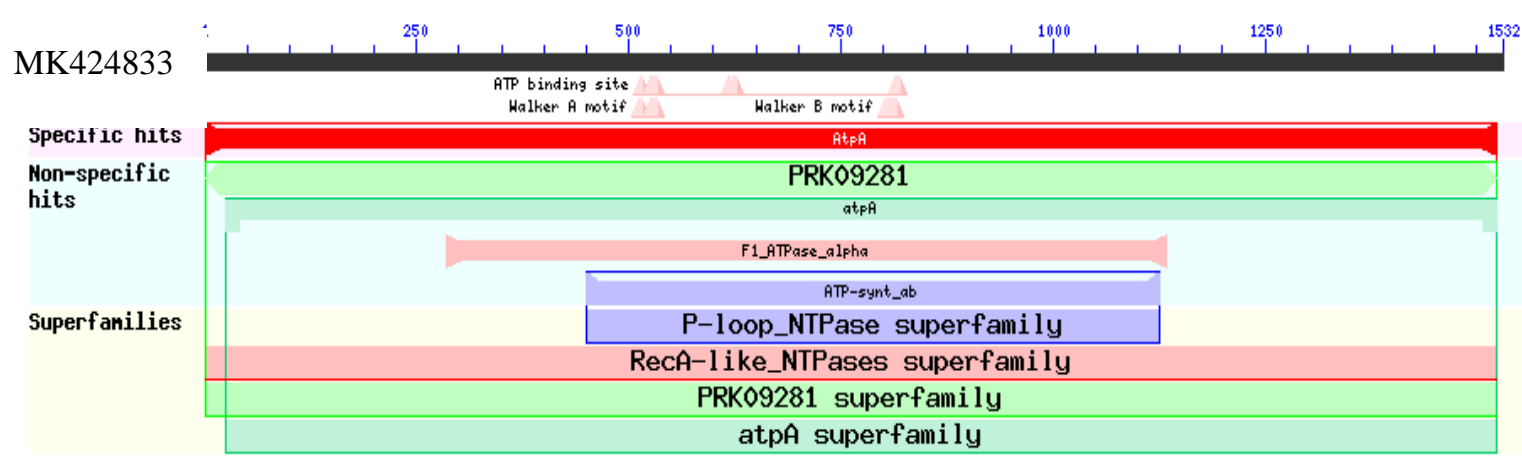

Fig. 1. Protein domains of the deduced amino acid sequence of the obtained atpl protein

\section{Characterization of $C$. roseus ATP1 mRNA:}

RNA sequences raw data was used to obtain cDNA ATP1 gene through C. roseus tissues. Obtained atpl DNA gene (accession no. MK424833) as a reference in CLC genomics workbench, with all RNA-seq data of different tissues (flower with accession no. SRR1271859, stem with accession no. SRR122253, leaf with accession no, SRR342017, hairy root with accession no. SRR122258, root with accession no. SRR1271858, and seedling with accession no. SRR5133636) were used. ATP1 cDNA sequences of different tissues were submitted to NCBI under accession no. MK424832 (flower atp1), accession no MK424831 (stem atp1), accession no MK424830 (leaf atp1), accession no MK424829 (hairy root atp1), accession no MK424828 (root atp1) and accession no MK424827 (seedling atp1).

\section{Analysis of RNA editing in ATP1 transcript and deduced amino acids:}

Deferential RNA editing sites of mitochondrial ATPl transcript were characterized across C. roseus tissues. RNA editing appeared from $\mathrm{C}$ to $\mathrm{T}$ in five editing loci (nucleotide no. C1039, C1178, C1292, C1415, C1490) in flower and leaf, and four in other tissues (Table S1, Fig.2, 3, 4). Three edits of mitochondrial ATP1 (C1039, C1292, C1415) were identified in all C. roseus tissues. However, RNA editing in site C1178 of mitochondrial ATPI transcript was only detected in flower, leaf and hairy root, but C1490 editing site was absent only in hairy root tissue (Table S1, Fig. 2, 3, 4). 
Table (S1). Atpl gene C-to-U editing events using reads derived from total RNA-seq.

\begin{tabular}{|c|c|c|c|c|c|c|}
\hline tissues & Nucleotide position & AA change & AA position & Total coverage & Edited coverage & \% Editing \\
\hline \multirow[t]{5}{*}{ Flower } & 1039 & P-S & 2 & 500 & 440 & 88 \\
\hline & 1178 & S- L & 13 & 678 & 447 & 66 \\
\hline & 1292 & P- L & 15 & 800 & 760 & 95 \\
\hline & 1415 & P- L & 21 & 873 & 846 & 97 \\
\hline & 1490 & P-L & 27 & 755 & 709 & 94 \\
\hline \multirow[t]{5}{*}{ leaf } & 1039 & P-S & 2 & 300 & 267 & 89 \\
\hline & 1178 & S- L & 13 & 350 & 185 & 53 \\
\hline & 1292 & P- L & 15 & 400 & 400 & 100 \\
\hline & 1415 & P- L & 21 & 450 & 387 & 86 \\
\hline & 1490 & P-L & 27 & 466 & 349 & 75 \\
\hline \multirow[t]{5}{*}{ Stem } & 1039 & P-S & 2 & 232 & 232 & 100 \\
\hline & 1178 & S- L & 13 & 213 & 0 & 0 \\
\hline & 1292 & P- L & 15 & 346 & 346 & 100 \\
\hline & 1415 & P- L & 21 & 541 & 541 & 100 \\
\hline & 1490 & P-L & 27 & 419 & 389 & 93 \\
\hline \multirow[t]{5}{*}{ Root } & 1039 & P-S & 2 & 223 & 223 & 100 \\
\hline & 1178 & S- L & 13 & 230 & 0 & 0 \\
\hline & 1292 & P- L & 15 & 362 & 333 & 92 \\
\hline & 1415 & P- L & 21 & 340 & 261 & 77 \\
\hline & 1490 & P-L & 27 & 240 & 220 & 92 \\
\hline \multirow[t]{5}{*}{ Hairy root } & 1039 & P-S & & 255 & 221 & 87 \\
\hline & 1178 & S- L & & 345 & 279 & 81 \\
\hline & 1292 & P- L & & 243 & 238 & 98 \\
\hline & 1415 & P- L & & 258 & 250 & 97 \\
\hline & 1490 & P-L & & 306 & 0 & 0 \\
\hline \multirow[t]{5}{*}{ seedling } & 1039 & P-S & & 400 & 324 & 81 \\
\hline & 1178 & S- L & & 463 & 0 & 0 \\
\hline & 1292 & P- L & & 432 & 393 & 91 \\
\hline & 1415 & P- L & & 350 & 350 & 100 \\
\hline & 1490 & P-L & & 395 & 209 & 53 \\
\hline
\end{tabular}

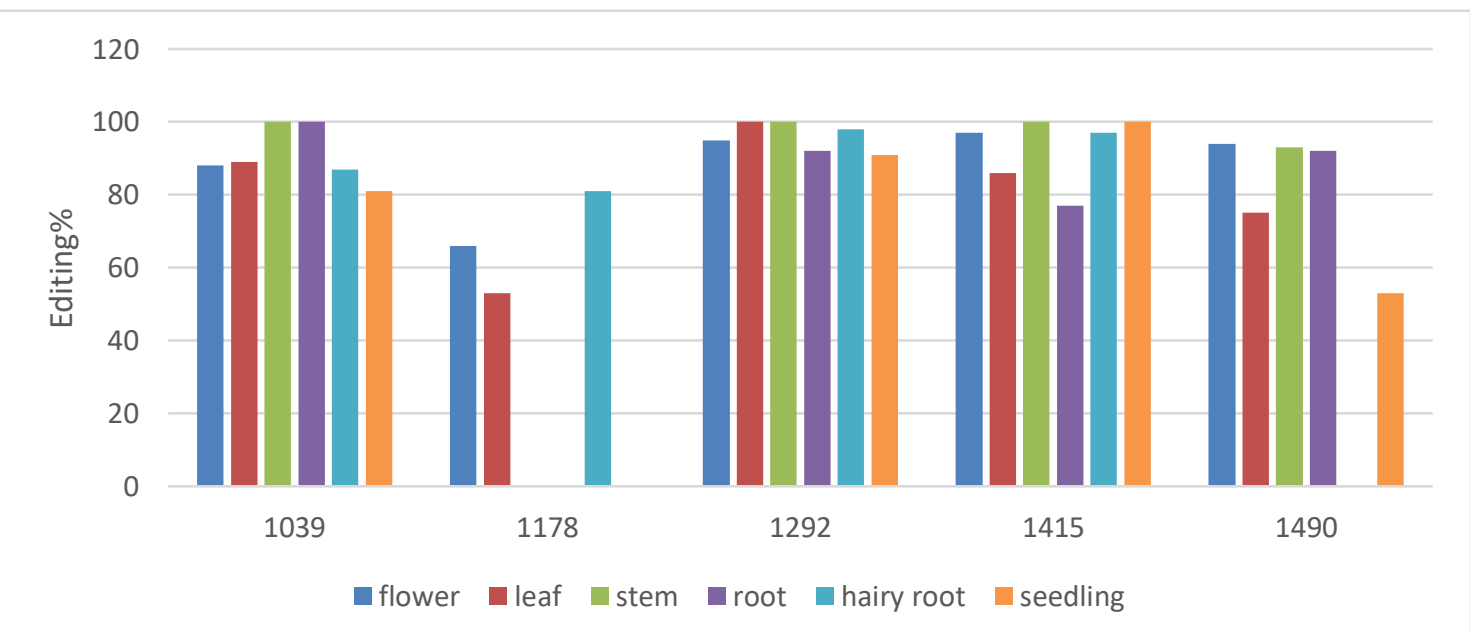

Fig 2. RNA editing sites of ATP1 gene in Catharanthus roseus tissues and amino acids changes. 
Protein alignment of ATP 1 was done and illustrated that edits caused an alteration in actual amino acids to leucine amino acid. One editing site (C1039) across RNA-seq data of $C$. roseus tissues was showing the change in amino acid proline to serine (Pro-Ser) (Table S1, Fig. 2).

Table 1. Accession numbers, description (organism Latin name) and the calculated e-value of homologous sequences to C. roseus atp1 gene.

\begin{tabular}{|c|c|c|c|c|c|c|}
\hline Description & Max score & Total score & Query cover & E value & Ident. & Accession \\
\hline Rhazya stricta mitochondrion, complete genome & 2737 & 2737 & $100 \%$ & 0.0 & $99 \%$ & KJ485850.1 \\
\hline $\begin{array}{c}\text { Guettarda scabra voucher Rova } 2260(\mathrm{~GB}) \text { atp1 } \\
\text { gene }\end{array}$ & 2721 & 2721 & $100 \%$ & 0.0 & $99 \%$ & KY638165.1 \\
\hline $\begin{array}{l}\text { Hymenodictyon parvifolium voucher B. Bremer } \\
\qquad 3809 \text { atp1gene }\end{array}$ & 2715 & 2715 & $100 \%$ & 0.0 & $99 \%$ & KY638167.1 \\
\hline $\begin{array}{c}\text { Hillia triflora voucher Bremer } \\
\text { gene }\end{array}$ & 2715 & 2715 & $100 \%$ & 0.0 & $99 \%$ & KY638166.1 \\
\hline $\begin{array}{l}\text { Luculia grandifolia voucher B. Bremer } 2713 \text { (S) } \\
\text { atp1 gene }\end{array}$ & 2715 & 2715 & $100 \%$ & 0.0 & $99 \%$ & KY638133.1 \\
\hline $\begin{array}{l}\text { Rondeletia odorata voucher Bremer \& Andreasen } \\
\qquad 3504 \text { atp1 gene }\end{array}$ & 2710 & 2710 & $100 \%$ & 0.0 & $99 \%$ & KY638181.1 \\
\hline $\begin{array}{l}\text { Isertia laevis voucher B. Bremer, K. Andreasen, } \\
\text { A. Backlund, J. Kukka \& B. Sennblad } 3364 \\
\text { (UPS) atp1 gene }\end{array}$ & 2704 & 2704 & $100 \%$ & 0.0 & $99 \%$ & KY638168.1 \\
\hline $\begin{array}{c}\text { Cubanola domingensis voucher Bremer } 4500 \text { (S) } \\
\text { atp1 gene }\end{array}$ & 2704 & 2704 & $100 \%$ & 0.0 & $99 \%$ & KY638159.1 \\
\hline $\begin{array}{c}\text { Posoqueria latifolia voucher Bergius Botanical } \\
\text { Garden SU-C- } 88.10 \text { atp1 gene }\end{array}$ & 2704 & 2704 & $100 \%$ & 0.0 & $99 \%$ & KY638158.1 \\
\hline Sipanea sp. NW-2017 voucher Rova et al. 1981 & 2699 & 2699 & $100 \%$ & 0.0 & $98 \%$ & KY638185.1 \\
\hline
\end{tabular}

According to Beijing Institute of Genomics, atpl editing sites were observed in 17 plant species. 15, 14 and 13 ATP1 edits were detected in Phaeoceros laevis, Phoenix dactylifera and Psilotum nudum, respectively. Citrullus lanatus, Rhazya stricta, Arabidopsis and Brassica napus had approximately the same total number of edits. The rest of the species had generally 1 to 3 ATP1 edits [20]. This study identified five editing sites in ATP1 transcript of C. roseus (Table2). However, other studies indicated that the RNA editing status of ATP1 transcript was detected at 6 sites (C1110, C1178, C1292, C1415, C1425 and C1484) in Arabidopsis mitochondria and five sites in G. hirsutum (C1039, C1064, C1216, C 1292 and C1415) [20, 34]. All these sites were reported in other plant species except C1490 which is reported for the first time in this study. ATP1 edits modified original amino acids to leucine except in position C1039 that was changed to serine. Leucine and serine amino acid are essential for ATP synthase activity in cellular respiration [31]. The high ATP level seems to depend on the number of edits as well as C1178. Three edits of ATPl gene transcripts Fig 4. QRT-PCR validation of Catharansaus roseus atpl editing sites different organs (C1039, C1292 and C1415) were detected in all $C$. roseus tissues. The most frequent number of edits appeared in flower and leaf tissues of $C$. roseus compared to other tissues.

Table 2. Primer sequences along to be utilized in validating RNA-Seq dataset of $C$. roseus via qRT-PCR. The actin gene was used as the house-keeping gene.

\begin{tabular}{|c|c|c|}
\hline Position & $\mathrm{F} \quad 5^{\prime} \longrightarrow 3^{\prime}$ & $\longrightarrow 3^{\prime}$ \\
\hline \multirow[t]{2}{*}{1039} & ATATTCCCACTAATGTGATCC & \multirow[t]{2}{*}{ TCGCGATATTGTGCCAATTC } \\
\hline & ATATTCCCACTAATGTGATCT & \\
\hline \multirow[t]{2}{*}{1178} & GAAACAAGTCTGTGGTAGTTC & \multirow[t]{2}{*}{ CAGCTGCATAAATGACTAGA } \\
\hline & GAAACAAGTCTGTGGTAGTTT & \\
\hline \multirow[t]{2}{*}{1292} & TGCAAGGCTGACAGAAGTACC & \multirow[t]{2}{*}{ TCTAAAAAGGATTGTAGTA } \\
\hline & TGCAAGGCTGACAGAAGTACT & \\
\hline \multirow[t]{2}{*}{1415} & \multirow[t]{2}{*}{ TGATGCTGCGACTCAGGCAT } & TTCTGGTTTTACACTATTTG \\
\hline & & TTCTGGTTTTACACTATTTA \\
\hline \multirow[t]{2}{*}{1490} & \multirow[t]{2}{*}{ GTGATCGAATGCCACTAGA } & CTTTTAAGAATTCATCTG \\
\hline & & CTTTTAAGAATTCATCTA \\
\hline actin & TGGTCGTCCAAGACACACTG & CTCTTCAGGGGCAACACGAA \\
\hline
\end{tabular}




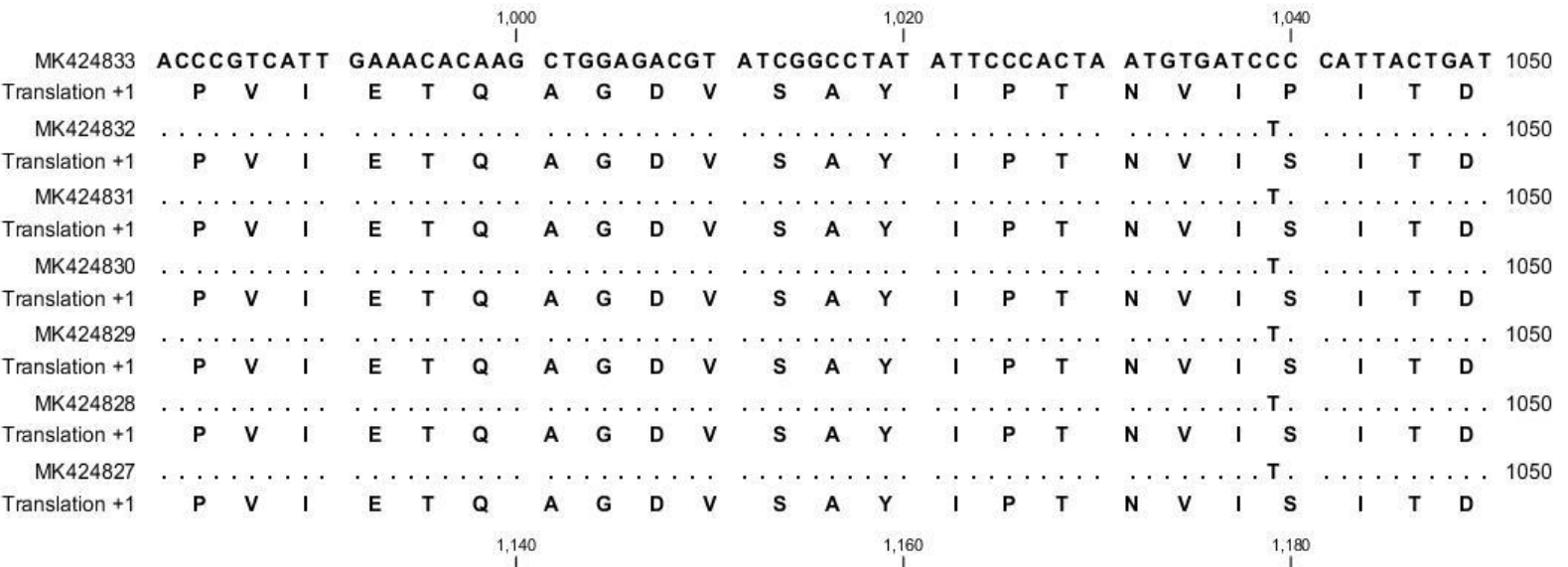

MK424833 TCAGTCGCGT CGgGTCCGCC GCTCAGTTGA AAACTATGAA ACAAGTCTGT GgtAgtTCAA AACTGGAAT 1190 $\begin{array}{llllllllllllllllllllllllllll}\text { Translation }+1 & V & S & R & V & G & S & A & A & Q & L & K & T & M & K & Q & V & C & G & S & S & K & T & E & L\end{array}$

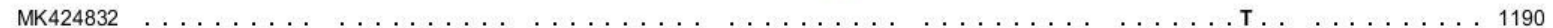

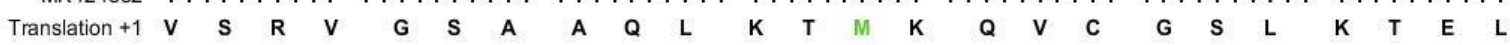

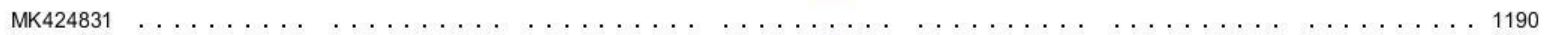

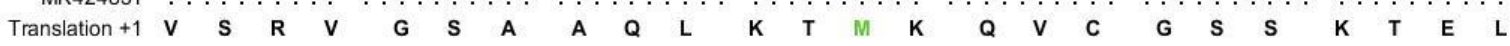

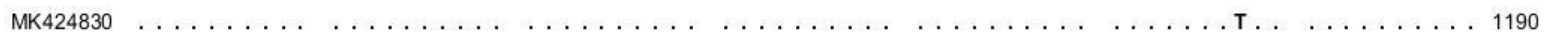

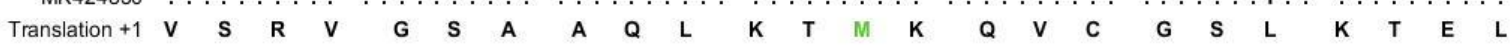

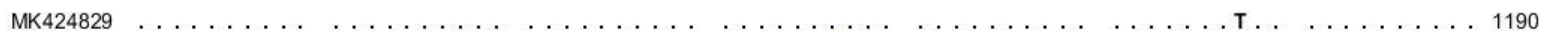

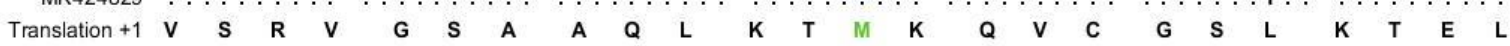

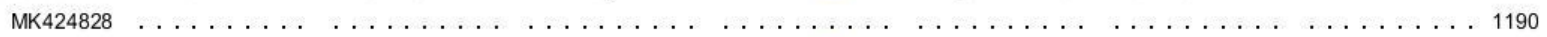

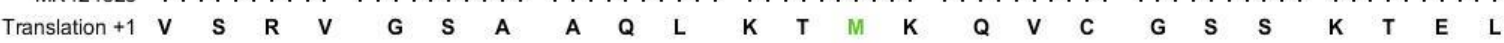

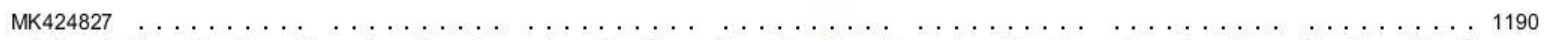

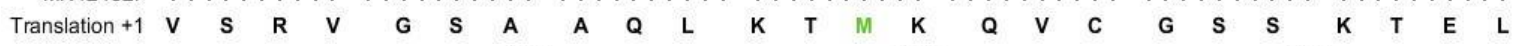

$$
1,280
$$

MK424833 CTCAATAGAG GTGCAAGgCT GACAGAAGTA CCGAAACAAC CACAATATGC ACCACTTCCA ATTGAAAAC 1330 $\begin{array}{llllllllllllllllllllllllll}\text { Translation }+1 & \text { T } & \text { N } & \text { R } & \text { G } & \text { A } & \text { R } & \text { T } & \text { T } & \text { E } & \text { V } & \text { P } & \text { K } & \text { Q } & \text { P } & \text { Q } & \text { Y } & \text { A } & \text { P } & \text { T } & \text { P } & \text { I } & \text { E } & \text { K }\end{array}$

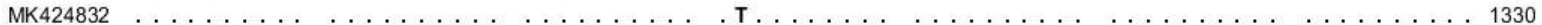

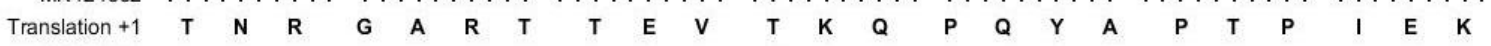

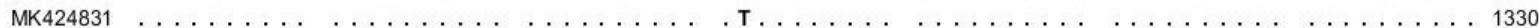

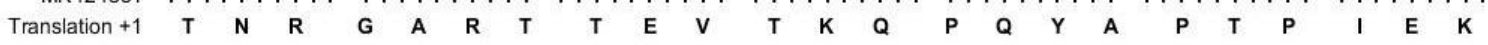

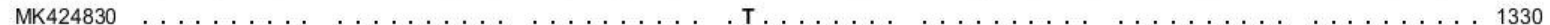

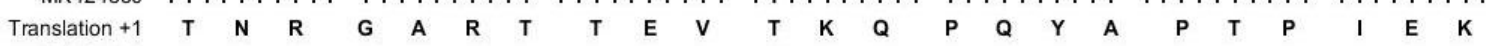

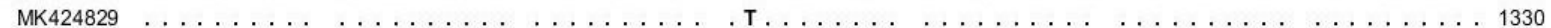

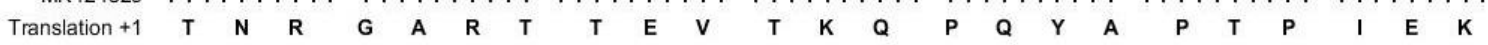

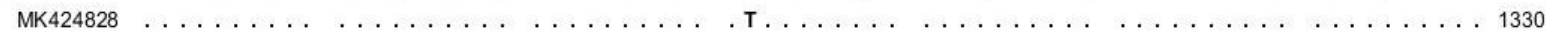

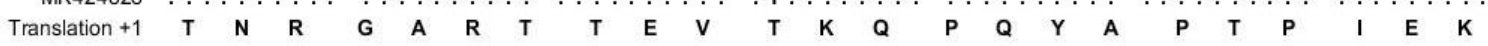

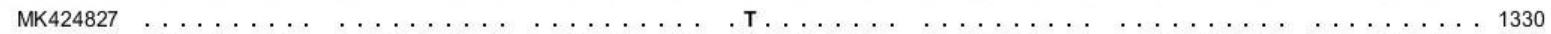

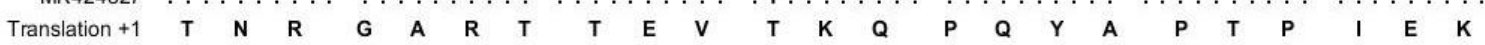

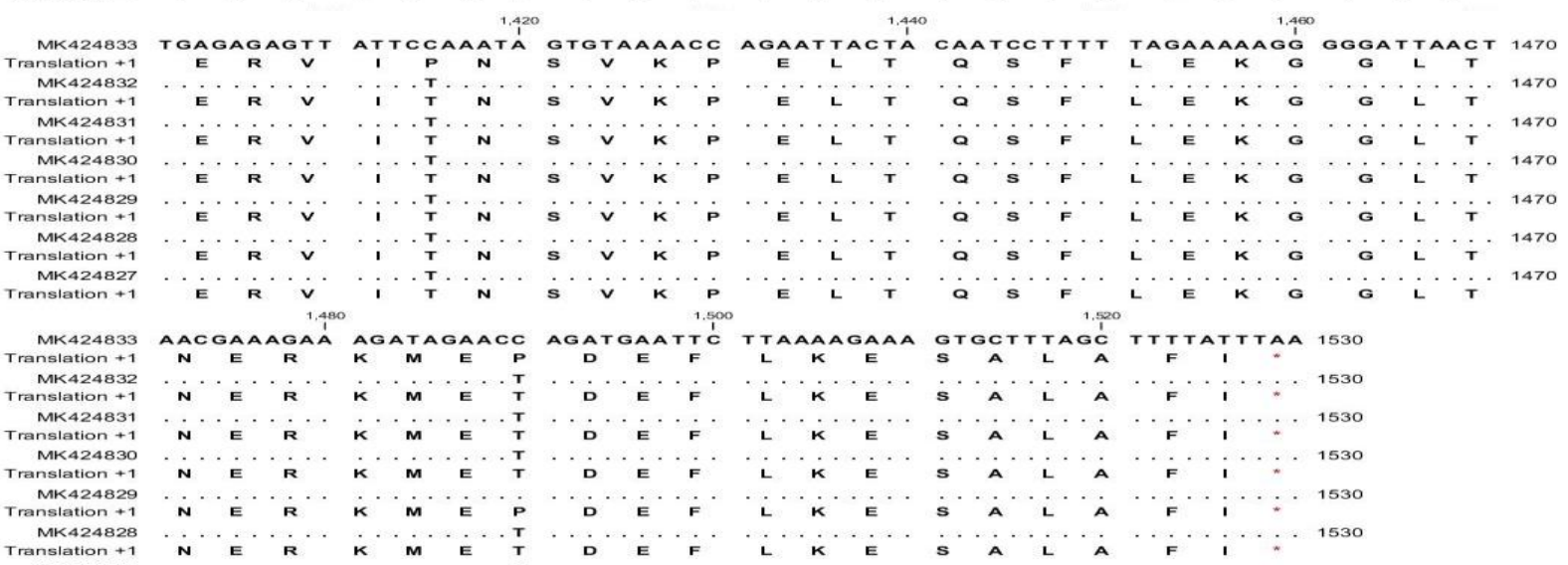

Fig 3. Differential RNA editing sites of mitochondrial atp1 gene across Catharansaus roseus tissues. ATP 1 cDNA sequences alignment of different tissues, MK424833 (atp1 DNA gene), MK424832 (flower atp1), accession no MK424831 (stem atp1), accession no MK424830 (leaf atp1), accession no MK424829 (hairy root atp1), accession no MK424828 (root atp1) and accession no MK424827 (seedling atp1). 


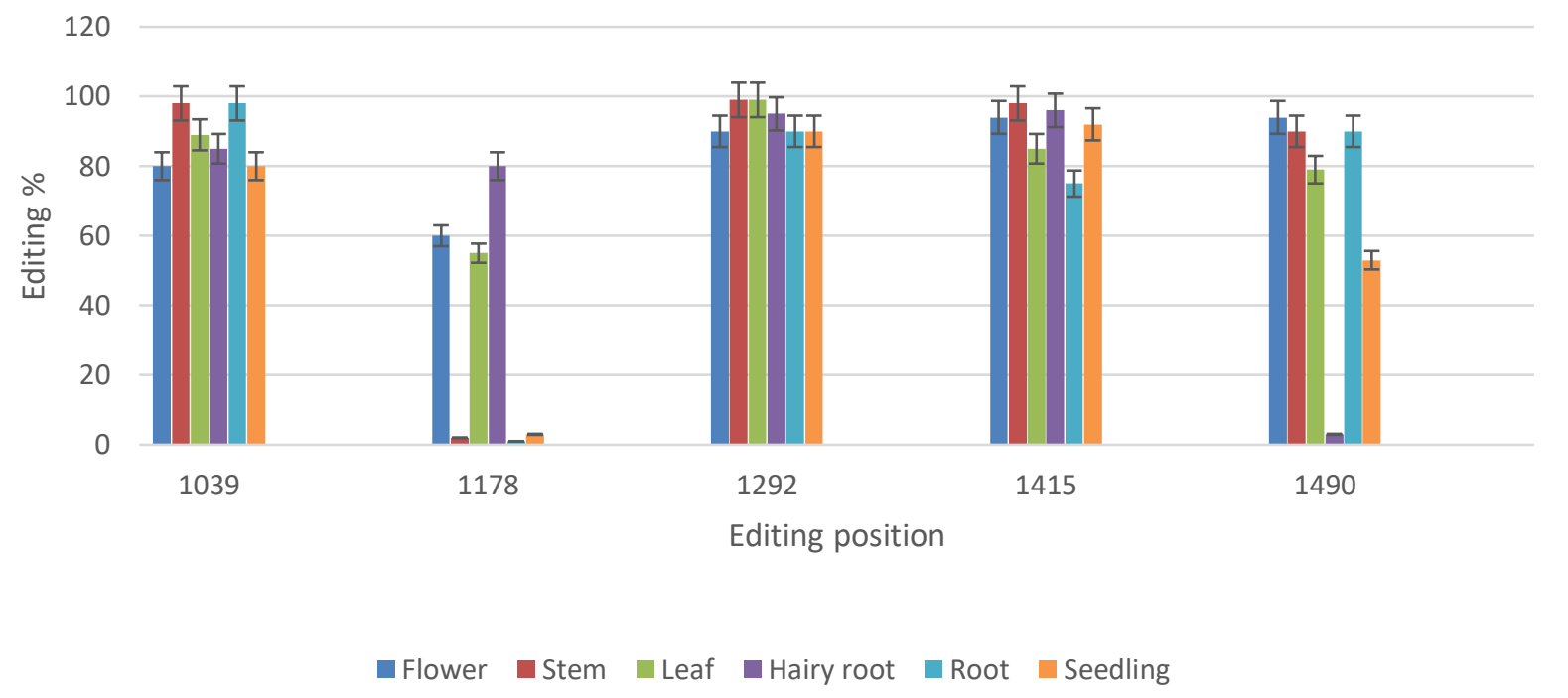

Fig 4. QRT-PCR validation of Catharansaus roseus atpl editing sites different organs

A C1178 edit on ATP1 transcript was only detected in flower, leaf, and hairy root of C. roseus whereas absent in root, stem and seedling. Furthermore, C1490 site of this gene was identified in all C. roseus tissues except in hairy root tissue; the editing on this site produced serine instead of proline. Serine plays an important role in the catalytic function of many enzymes [35], that is means the changes due to RNA editing in C1490 may increase the activity of ATPase subunit1. However, ATP measurements (Fig. 5) indicate that ATP production in hairy roots is more than stem, root and seedling, which have edited in C1490. This indicates that it may be no direct effect of editing in C1409 with ATP synthase activity. However, this needs studying the RNA editing in most related plant species to know the importance of this site in ATP1 activity. Also, to know if this site is common in these species or special for this plant, especially we found some plants are not needed editing in these sites like atp1 gene in Sipanea sp. and Posoqueria latifolia because there is $\mathrm{T}$ instead of $\mathrm{C}$ in DNA sequence (Table 1). Accordingly, editing site (C1178) might be related to cellular needs of ATP, because all tissues which have editing in C1178 have a high rate of ATP production (Fig. 5). Furthermore, this explains why Mutation in editing site atp1-1178 caused delays in Arabidopsis growth and development [22].

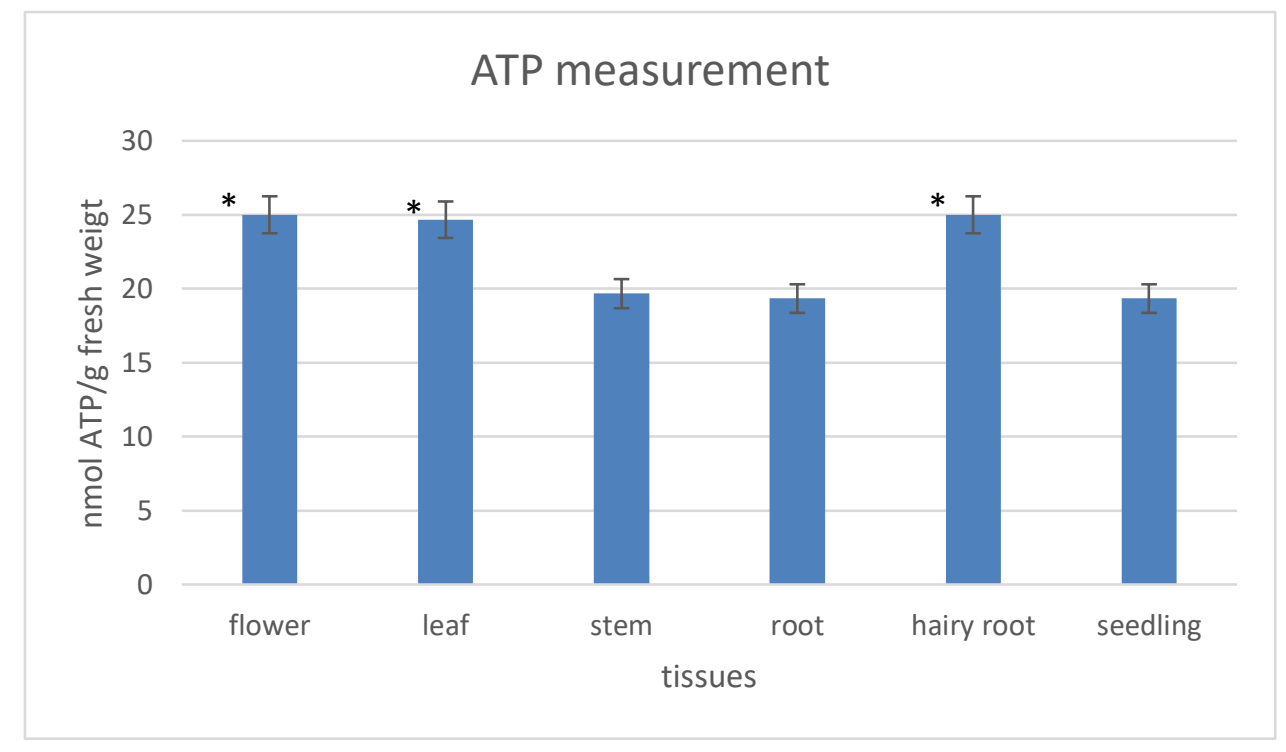

Fig. 5. Atp measurement in different tissues. Data are expressed (nmol/g FW) as means with \pm SD of three biological replicates. Independent ANOVA test using SPSS Statistics Software. * indicate a significant difference between tissues $\mathrm{P}<0.05$. FW, Fresh 
weight. The editing sites in ATP1 gene transcripts of C. roseus C1039, C1292 and C1415 may be vital ATP synthase the activity of due to the high editing in these sites in all tissues.

\section{CONCLUSION}

RNA editing takes place in 5 sites of $C$. roseus atpl gene transcripts. These editing sites are mostly conserved across plant species except C1490, which a new editing site is. Three edits of ATP1 gene transcripts (C1039, C1292, and C1415) were detected in all C. roseus tissues, which describe the vital function of this editing. However, the C1178 edit was only detected in flower, leaf, and hairy root, but it was absent in root, stem, and seedling, So it is thought that it is effective significantly in ATP production. C1490 site was identified in all tissues except hairy root, although the ATP amount of hairy root is kindly high. The effect of C1490 editing needs more studies to confirm the role of this editing in ATP production. The differential editing of this gene among plant tissues may shed light on understanding the relationship between RNA editing and cellular respiration efficiency.

\section{REFERENCES}

[1] Bentolila, S., Oh, J., Hanson, M., Bukowski, R. (2013). Comprehensive High-Resolution Analysis of the Role of an Arabidopsis Gene Family in RNA Editing. PLoS genetics. 9. e1003584. 10.1371/journal.pgen.1003584.

[2] Gott, J.M. and Emeson, R.B. (2000). FUNCTIONS AND MECHANISMS OF RNA EDITING. Annual Review of Genetics. 34(1): p. 499-531.

[3] Su, A.A.H. and Randau L. ( 2011). A-to-I and C-to-U editing within transfer RNAs. Biochemistry (Moscow). 76(8): p. 932.

[4] Bar-Yaacov, D., Mordret, E., Towers, R., Biniashvili, T., Soyris, C., Schwartz, S., Dahan, O., Pilpel, Y. (2017). RNA editing in bacteria recodes multiple proteins and regulates an evolutionarily conserved toxin-antitoxin system. Genome research. 27(10): p. 1696-1703.

[5] Takenaka, M., Verbitskiy, D., Zehrmann, A., Härtel, B., Bayer-Császár, E., Glass, F., Brennicke, A. (2014). RNA editing in plant mitochondria - Connecting RNA target sequences and acting proteins. Mitochondrion,. 19: p. 191-197.

[6] Nishikura, K. (2010). Functions and regulation of RNA editing by ADAR deaminases. Annual review of biochemistry. 79: p. 321-349.

[7] Castandet, B. and Araya A. (2011). RNA editing in plant organelles. Why make it easy? Biochemistry (Moscow). 76(8): p. 924.

[8] Takenaka, M., Zehrmann, A., Verbitskiy, D., Härtel, B., Brennicke, A. (2013). RNA Editing in Plants and Its Evolution. Annual Review of Genetics. 47(1): p. 335-352.

[9] Terajima, H., Yoshitane, H., Ozaki, H., Suzuki, Y., Shimba, S., Kuroda, S., Iwasaki, W., Fukada, Y. (2016). ADARB1 catalyzes circadian A-to-I editing and regulates RNA rhythm. Nature Genetics. 49: p. 146.

[10] Small, I. ( 2010). Plant RNA editing AU - Chateigner-Boutin, Anne-Laure. RNA Biology. 7(2): p. 213-219.

[11] Ruwe, H., Castandet, B., Schmitz-Linneweber, C., Stern, D. B. (2013). Arabidopsis chloroplast quantitative editotype. FEBS Letters. 587(9): p. 1429-1433.

[12] Brehme, N., Bayer-Császár, E., Glass, F., Takenaka, M. (2015). The DYW Subgroup PPR Protein MEF35 Targets RNA Editing Sites in the Mitochondrial rpl16, nad4 and cob mRNAs in Arabidopsis thaliana. PLOS ONE. 10(10): p. e0140680.

[13] Chinnery, P.F., and Hudson G. (2013). Mitochondrial genetics. British medical bulletin. 106(1): p. 135-159.

[14] Park, S., Ruhlman, T. A. Sabir, J.S.M., Mutwakil, M.H.Z., Baeshen, M. N., Sabir, M. J., Baeshen, N. A., Jansen, R. K. (2014). Complete sequences of organelle genomes from the medicinal plant Rhazya stricta(Apocynaceae) and contrasting patterns of mitochondrial genome evolution across asterids. BMC Genomics. 15(1): p. 405.

[15] Heazlewood, J.L., Whelan, J., Millar, A.H. (2003). The products of the mitochondrial orf25 and orfB genes are FO components in the plant F1FO ATP synthase. FEBS Letters. 540(1-3): p. 201-205.

[16] Sabar, M., Balk, J., Leaver, C.J. (2005). Histochemical staining and quantification of plant mitochondrial respiratory chain complexes using blue-native polyacrylamide gel electrophoresis. The Plant Journal. 44(5): p. 893901.

[17] Liu, Y.J., Xiu, Z.H., Meeley, R.,Tan, B. C. (2013). Empty pericarp5 encodes a pentatricopeptide repeat protein that is required for mitochondrial RNA editing and seed development in maize. The Plant Cell. 25(3): p. 868-883. 
[18] Li, S.X., Song, Y.J., Zhang, Y.S., Wu, H.T., Guo, H., Zhu, K. J., Li, D.M., Zhang, H. (2017). Mitochondrial Complex V $\alpha$ Subunit Is Critical for Candida albicans Pathogenicity through Modulating Multiple Virulence Properties. Frontiers in Microbiology. 8(285).

[19] Rühle, T. and Leister, D (2015). Assembly of F1F0-ATP synthases. Biochimica et Biophysica Acta (BBA) Bioenergetics. 1847(9): p. 849-860.

[20] He, P., Xiao, G., Liu, H., Zhang, L., Zhao, L., Tang, M., Huang, S., Yingjie, A., Jianing, Y. (2018). Two pivotal RNA editing sites in the mitochondrial atpImRNA are required for ATP synthase to produce sufficient ATP for cotton fiber cell elongation. New Phytologist. 218(1): p. 167-182.

[21] Kong, X., Liu, D., Zheng, J., Khan, A., Li, B., Diao, Y., Zhou, R. (2019). RNA editing analysis of ATP synthase genes in the cotton cytoplasmic male sterile line H276A. Biological Research. 52(1): p. 6.

[22] Hammani K., des Francs-Small C.C., Takenaka M., Tanz S.K., Okuda K., Shikanai T., Brennicke A., Small I. (2011). The pentatricopeptide repeat protein OTP87 is essential for RNA editing of nad7 and atp1 transcripts in Arabidopsis mitochondria. The Journal of biological chemistry. 286(24): p. 21361-21371.

[23] Makki, R., Saeedi, A., Khan, T., Ali, H.M., Ramadan, A.M. (2019). Single nucleotide polymorphism analysis in plastomes of eight Catharanthus roseus cultivars. Biotechnology \& Biotechnological Equipment. 33(1): p. 419-428.

[24] Elsa G.C., Kevin L.C., Greg F.,, John P.H., David K. L., Maria M.L., Kranthi K.M., Ezekiel N., Weerawat R., Brieanne V., Marina V.H., Dean D., Thomas D.M., Sarah O'C., Buell C. R. (2012). Development of Transcriptomic Resources for Interrogating the Biosynthesis of Monoterpene Indole Alkaloids in Medicinal Plant Species. PLOS ONE. 7(12): p. e52506.

[25] Dugé de Bernonville T., Foureau E., Parage C., Lanoue A., Clastre M., Londono M.A., Oudin A., Houillé B., Papon N., Besseau S., Glévarec G., Atehortùa L., Giglioli-Guivarc'h N., St-Pierre B., De Luca V., O'Connor S.E., Courdavault V. (2015). Characterization of a second secologanin synthase isoform producing both secologanin and secoxyloganin allows enhanced de novo assembly of a Catharanthus roseus transcriptome. BMC Genomics. doi: 10.1186/s12864-015-1678-y. PMID: 26285573; PMCID: PMC4541752.

[26] Wang, M., Cui, L., Feng, K., Deng, P., Du, X., Wan, F., Weining, S., Nie, X., Comparative Analysis of Asteraceae. (2015). Chloroplast Genomes: Structural Organization, RNA Editing and Evolution. Plant Molecular Biology Reporter. p. 33.

[27] Rodrigues, N.F., Christoff, A. P., da Fonseca, G. C. Kulcheski, F. R., Margis, R. (2017) . Unveiling Chloroplast RNA Editing Events Using Next Generation Small RNA Sequencing Data. Frontiers in plant science. 8: p. 1686-1686. [28] Ford, S.R. and Leach, F. R. (1998). Bioluminescent Assay of the Adenylate Energy Charge. In Bioluminescence Methods and Protocols. Humana Press: Totowa, NJ. p. 69-81.

[29] Khlyntseva, S. V., Bazel', Y.R., Vishnikin, A.B., Andruch, V. (2009). Methods for the determination of adenosine triphosphate and other adenine nucleotides. Journal of Analytical Chemistry. 64(7): p. 657-673.

[30] Chase, C. D. (2007). Cytoplasmic male sterility: a window to the world of plant mitochondrial\&\#x2013;nuclear interactions. Trends in Genetics. 23(2): p. 81-90.

[31] Pedroso, J.A.B., Zampieri T.T., Donato J. (2015). Reviewing the Effects of 1-Leucine Supplementation in the Regulation of Food Intake, Energy Balance, and Glucose Homeostasis. Nutrients. 7(5): p. 3914.

[32] Hassanein, S. (2014). Characterization of ATP gene in Calotropis procera Mitochondrial Genome. Egyptian Journal of Genetics and Cytology. Vol. 43. p. 257 - 269.

[33] Shokry, A.M. Al-Karim, S., Ramadan, A., Gadallah, N., Al Attas, S.G., Sabir, J.S. M., Hassan, S. M., Madkour, M.A., Bressan, R., Mahfouz, M., Bahieldin, A.M. (2014). Detection of a Usp-like gene in Calotropis procera plant from the de novo assembled genome contigs of the high-throughput sequencing dataset. Comptes Rendus Biologies. 337(2): p. 86-94.

[34] Database, B.P.E. (2014). ATP1, A curated database of RNA editosome in plants. Beijing Institute of Genomics. Available from: http://bigd.big.ac.cn/ped/gene/atp1.

[35] Cooper, G.M. (2000). The chemistry of cells: the central role of enzymes as biological catalysts. The cell. 2000 . 